\title{
A CULTURA, DA GALAXIA GUTENBERG Á GALAXIA INTERNET
}

\section{Darío Villanueva}

Universidade de Santiago de Compostela 

Nas seguintes páxinas pretendo expoñer e someter a contraste certas ideas que me veñen preocupando, pero tamén poñer en común determinadas experiencias persoais, sempre referidas a un tema que non é menor: as posibilidades e límites da cultura nos momentos que nos toca vivir, no contexto da sociedade do coñecemento, da información e do que algúns, como José Terceiro e Gustavo Matias (Terceiro, Matías, 2001, p. 101), deron en chamar «dixitalismo», polo cal se entende «una nueva forma de cultura, enraizada en la tecnología y en la economía, que impregna los distintos ámbitos sociales de la actividad humana. Digitalismo o cultura digital, entendida como cultura instrumental [...] que ha venido a sustituir a la cultura general requerida a principios del siglo XX».

En 2003 repúxose, despois de sete lustros da súa última representación, a peza teatral de Antonio Buero Vallejo Historia de una escalera, estreada nunha data tan afastada como 1949. Baixo a dirección de Juan Carlos Pérez de la Fuente, o Centro Dramático Nacional levou á escena, no teatro María Guerrero de Madrid, este texto xa clásico no que a crítica valorou desde un principio o seu carácter de fondo drama que representa e denuncia o desespero existencial dunhas vidas marcadas polo lastre insuperable dunha esmagadora posguerra.

Asistín a unha desas funcións madrileñas nun serán primaveral no que o teatro se encheu dun público para min especialmente prometedor. Eran ducias de mozos e mozas adolescentes que, acompañados polos profesores dos seus centros educativos, acudían ao María Guerrero como quen vai de festa, o que me resultou doadamente comprensible: aquilo significaba tanto como substituír a rutina das aulas pola novidade fascinante dunha experiencia teatral que, dito sexa de paso, sempre formou parte do repertorio dos recursos educativos audiovisuais avant la lettre. É ben coñecido o intenso emprego do teatro polos centros de ensino de tradición anglosaxoa, sen esquecer, máis preto da nosa cultura, a mesma utilización da arte de Talía nos colexios xesuíticos. 
O balbordo preliminar non remitiu, porén, unha vez levantado o pano. Para o meu desconcerto, aquel público de xente moi nova reaccionou expresivamente sempre do mesmo xeito, de forma invariable, ás distintas escenas que conformaban os tres actos de Historia de una escalera: riron sen excepción, moitas veces ás gargalladas, sempre que remataba unha situación dramática ou un parlamento, e así escena a escena ata o propio final.

O que aquilo representaba era nin máis nin menos que a comprensión dun drama como se fose unha comedia, e isto sen a máis mínima marxe de dúbida. Antonio Buero Vallejo quixo representar, ao longo dun "percurso» temporal de trinta anos, como o drama da vida transmitía de pais a fillos as mesmas frustracións, os mesmos fracasos, un mesmo destino inmisericorde. Maniféstase todo isto a través de situacións repetitivas desenvolvidas no escenario desolador dunha escaleira que se nos figura como unha trampa ou cepo no que fican atrapadas as vidas tanto de Carmina e Urbano, de Fernando e Elvira, como da filla dos primeiros e do primoxénito dos segundos. Todos recordamos, no acto primeiro, o clímax que se produce cando Fernando, soñador abúlico, lle promete á súa noiva unha cadea de logros que os irá levando paulatinamente ao triunfo persoal e á felicidade amorosa, e todo remata cando o mozo, embebido nas súas fantasías, fai que se verta o leite que Carmina vén de mercar ao empurralo co seu pé. Esta recreación do amargo "conto da leiteira», que probablemente xa non lles di nada aos máis novos, foi rematada cun risoño aplauso do auditorio, encantado, ao parecer, polo cómico da situación e pola torpeza do protagonista.

Para min aquela resposta, a recepción unánime da peza de Buero Vallejo polo público máis novo en clave cómica, representou nin máis nin menos que a morte do drama, a lectura dunha peza destas características como comedia, xéneros antitéticos entendidos como tales desde que o propio Aristóteles formulase a súa teoría poética.

George Steiner, hai case que cincuenta anos, estudou o gran tema da morte da traxedia. Todas as persoas temos conciencia do sino tráxico que se ceba nalgunhas vidas, pero a traxedia como xénero teatral tivo o seu momento e hai séculos que desapareceu. As forzas tráxicas son irracionais e insuperables. Cando as causas da catástrofe tráxica son afrontables con posibilidade de reducilas ou erradicalas, daquela entramos xa na esfera do drama, como acontece en Historia de una escalera. Unha sociedade mellor conformada, máis aberta, con máis 
incentivos e posibilidades e un temperamento máis decidido, menos apático e acomodaticio dos protagonistas, cambiaría por completo a súa sorte e levaría á realización positiva das súas vidas.

Buero Vallejo non quixo, non obstante, representar esa posibilidade na súa peza; o seu intento era sacudir dramaticamente o público, xerando nel a catarse de conxurar as súas propias eivas, as que tiñan os espectadores de 1949 e temos tamén os de hoxe, mediante a representación do sufrimento de quen, sobre o escenario, nos mimetiza. Mais un grupo homoxéneo, por idade e por formación, de espectadores de 2003 non se sentiu concernido por semellante proposta teatral, e de feito transformou o drama de Buero nunha comedia, fonte de ledicia, de riso, de festa. Certamente, o teatro, desde as súas orixes, é festa nun senso litúrxico, ritual, en certo modo mítico. É a festa en que a sociedade, colectiva, de forma tribal, se recoñece a si mesma na pantomima que se representa sobre a escena, pero unhas veces o froito da festa, a catarse, é risoña, mentres que noutras é aceda. Se aquel público mozo ría un drama como comedia, de feito reducía a esta última posibilidade toda manifestación teatral. E como así?

Reflexionando sobre o acontecido naquel serán no María Guerrero, fíxoseme moi presente unha poderosa mediación que podería ter influído no fenómeno: a mediación televisiva. Aqueles mozos poida que participasen por primeira vez nunha representación teatral, como acreditaba quizais o estado de euforia con que se achegaron ao coliseo. Pero, cantas horas de televisión terían xa asimiladas na súa curta vida?

Por outra parte, en moitas desas horas, por caso nas ficcións televisivas que se lles ofreceran, o rexistro non soamente tería sido cómico senón que estaría acompañado do reforzo dunhas risas enlatadas que desde a propia banda sonora da emisión inducirían unha resposta unanimemente unívoca. En certo modo, a televisión é fundamentalmente comedia, ata o extremo de que poida chegar a suxerirlles ás novas xeracións unha identidade funcional entre a comedia e o espectáculo televisivo.

O paso seguinte na miña argumentación levoume ao terreo do que será o motivo central destas páxinas. A pregunta é doada: estaría asistindo a unha manifestación nidia dun cambio radical de sensibilidade entre os máis novos? Despois de que durante vinte e cinco séculos as persoas reaccionasen diante da traxedia como traxedia e diante da comedia como comedia, a poderosa media- 
ción televisiva da que falamos sería quen de cambiar tan profundamente os alicerces da condición humana e a nosa capacidade de comprensión ata o extremo de abrir unha fenda insuperable entre Antonio Buero Vallejo, ou mesmo a miña xeración, nacida cando Historia de una escalera estaba xa escrita, e os espectadores potenciais de hoxe, acubillados ademais por un contorno de ensino ao que lle interesaba manter a ligazón entre proceso educativo e representación audiovisual a través do teatro?

Nos anos sesenta do século pasado, unha rapaza que se acabada de licenciar, Janet Murray, mentres non lograba unha bolsa para doutorarse en Literatura inglesa, entrou a traballar como programadora na compañía IBM. Acadado finalmente ese título académico, abandonou a actividade docente e investigadora para incorporarse ao "Laboratorio para a tecnoloxía avanzada en Humanidades» do MIT, onde actuaba xa como director Nicholas Negroponte (1999), o autor de Being Digital. Anos máis tarde, Janet publicaba un libro sobre o futuro da narrativa no ciberespazo, onde recollía a mesma sensación que eu experimentara no transcurso da representación antes comentada: «El nacimiento de un nuevo medio de comunicación es al mismo tiempo fuente de entusiasmo y temor. Cualquier tecnología industrial que extienda espectacularmente nuestras capacidades nos pone también nerviosos al cuestionar nuestro concepto de humanidad» (Murray, 1999, p. 13).

Máis radical se manifestara con anterioridade un coñecido crítico literario norteamericano, Sven Birkerts, que, en 1994, non dubidara en publicar The Gutenberg Elegies, libro, como o seu título dá a entender, moi pesimista verbo do futuro da lectura na era electrónica. Birkerts enfía unha manchea de interrogantes a propósito de como as novas tecnoloxías poden estar a deformar a nosa condición humana, fragmentando a nosa identidade, erosionando a profundidade da nosa conciencia. E conclúe cunhas palabras que inciden directamente no problema que constitúe o miolo do noso futuro cultural: a educación: «Estamos renunciando a la sabiduría, cuya consecución ha definido durante milenios el núcleo mismo de la idea de cultura; a cambio nos estamos adhiriendo a la fe en la red» (Birkerts, 1999, p. 293).

En ambas as dúas voces citadas, Janet Murray e Stephen Birkerts, resoa o pensamento dunha das figuras intelectuais máis salientables da segunda metade do século XX, o crítico literario canadense Marshall McLuhan, que fundamen- 
taba en 1962 o seu revelador libro The Gutenberg Galaxy na afirmación de que toda tecnoloxía tende a crear un novo contorno para os seres humanos. McLuhan entendía os avances tecnolóxicos como extensións dos nosos propios corpos, dos nosos sentidos, o que implica en todo caso un ronsel de consecuencias psíquicas e sociais. A tecnoloxía do alfabeto fonético, que data de tres mil ou tres mil cincocentos anos antes de Cristo, trasladou os seres humanos desde o mundo máxico do oído e da tribo, onde a comunicación se baseaba exclusivamente na oralidade, ao mundo neutro do visual. Semellante cambio representa, inicialmente, un empobrecemento notable na vida imaxinativa, sensitiva e emocional. O descubrimento da imprenta de tipos móbiles potencia extraordinariamente a cultura do alfabeto, ao multiplicar mecanicamente os escritos e posibilitar o seu espallamento polo mundo adiante. McLuhan atribúelle á imprenta non só o reforzamento do individualismo senón tamén a aparición das nacionalidades modernas. E no seu percorrido, logo de salientar o que representou, contra o ano 1844, o descubrimento do telégrafo, chegamos ao que nalgún momento da súa obra o canadense denomina «a constelación de Marconi», chamada a eclipsar a Galaxia Gutenberg. McLuhan adoita falar, xa que logo, dos «medios eléctricos» para se referir tamén á radio, ao cine, ao teléfono e á televisión ou «iconoscopio», que, nas súas propias palabras, «ha acrecentado y exteriorizado todo nuestro sistema nervioso central, transformando así todos los aspectos de nuestra existencia social y psíquica» (McLuhan, Zingrone, 1998: p. 293). Contraído para nós o globo por mor dos medios eléctricos mencionados, o universo redúcese a unha aldea, rexorde o tribalismo primitivo, prealfabético, e así se poden comprender fenómenos de gregarismo como o daquela lectura cómica dun drama por parte dos rapaces madrileños, por poñer un exemplo concreto.

En 1966, cando Marshall McLuhan había pouco que rematara as achegas formuladas inicialmente en A Galaxia Gutenberg (1962) e desenvolvidas axiña por un segundo libro, Understanding Media (1964), en Europa, Umberto Eco (1968), daquela un mozo investigador do Medievalismo e a Semioloxía, daba ao prelo o seu famoso libro Apocalípticos e integrados ante a cultura de masas, no que expresa a inquedanza dos humanistas pola evidente democratización dos bens culturais promovida pola proliferación de mensaxes transmitidas a través de novas canles. A súa observación de partida era incontestable: desde unha con- 
cepción elitista, "la mera idea de una cultura compartida por todos, producida de modo que se adapte a todos, y elaborada a medida de todos, es un contrasentido monstruoso. La cultura de masas es la anticultura» (Eco, 1968, p. 12). Fronte a esta postura apocalíptica, Eco rexistra tamén a reacción optimista do integrado, que era a súa propia: a nova era representaba unha oportunidade única de ampliación do campo cultural contra a que, sobre todo, non cabía a indiferenza. A conclusión de Eco resultaba moi clara a este respecto: «El universo de las comunicaciones de masa -reconozcámoslo o no- es nuestro universo; y si queremos hablar de valores, las condiciones objetivas de las comunicaciones son aquéllas aportadas por la existencia de los periódicos, de la radio, de la televisión, de la música grabada y reproducible, de las nuevas formas de comunicación visual y auditiva» (1968, p. 15).

Hai un momento rexistrabamos a inquedanza apocalíptica de Janet Murray e Stephen Birkerts xa non ante a cultura de masas de que trata Eco, senón fronte ao ciberespazo e ao universo dixital. Pero esa mesma reacción é rexistrable case desde o comezo dos tempos. A revolución tecnolóxica da escritura é relativamente recente. $\mathrm{O}$ homo sapiens data de hai uns cincuenta mil anos e soamente contra o 3000 ou o 3500 antes de Cristo os sumerios descubriron en Mesopotamia o alfabeto fonético. Cincuenta séculos despois, aproximadamente, xorde a revolución de Gutenberg: cando Camões, Shakespeare e Cervantes escriben trátase aínda dunha conmoción apenas asimilada.

En certo modo, esta segunda revolución potenciou extraordinariamente a precedente porque foi a impresión e non a escrita o que de feito rectificou a palabra e con ela a actividade intelectual. A cultura do manuscrito seguía a ser marxinalmente oral. $\mathrm{O}$ auditivo continuou, xa que logo, dominando por algún tempo despois de Gutenberg. Finalmente, porén, a imprenta mudou o predominio do oído no mundo do pensamento e da comunicación polo da vista. A imprenta sitúa as palabras no espazo dun xeito moito máis rotundo do que nunca antes o fixera o alfabeto por si mesmo, e isto determinou unha verdadeira transformación da conciencia humana.

Xustamente, este feito xa o denunciara con tinta apocalíptica, como ben se lembrará, o propio Platón, que no seu diálogo Fedro ou do amor pon en boca de Sócrates o relatorio de como o deus Theuth inventou a escritura. Cando lle expuxo o seu descubrimento ao rei Thamus, gabándose dos seus beneficios, o 
imperante mostrouse por completo contrario á innovación, por considerala sumamente prexudicial para a memoria e, sobre todo, para a verdadeira sabedoría, que só se debería aprender oralmente dos mestres.

Da mesma opinión participa Sócrates, como non podería ser doutro xeito no caso do inventor da maiéutica. O discurso escrito está morto, non é máis que un van simulacro do auténtico, do discurso vivo, «escrito cos carácteres da ciencia na alma do que estuda», que xustamente por iso pode «defenderse por si mesmo», "falar e calar a tempo». Os outros, os discursos dos libros, "cando os oes ou os les, coidas que pensan; mais, pedídelles algunha explicación sobre o obxecto que conteñen e responderanvos sempre o mesmo» (Platón, 1984, p. 658-659).

Comentando estas páxinas platónicas sobre a orixe da escritura, Ignacio Gómez de Liaño argumenta que, fronte á escrita superficial do sofista, o auténtico diálogo filosófico é «la operación característica de ese amor superior, en el que el maestro desempeña las funciones de amante y mayeuta» (1982, p. 151-159). Recentemente, George Steiner (2004) ten reparado tamén nesa compoñente erótica, de sedución, que acompaña o contacto persoal entre mestre e discípulo desde Sócrates e Alcibíades, que non pode, loxicamente, darse mediante a relación mediatizada, en certo modo dislocada, como a que existe entre autor e lector dun libro.

Convén lembrar aquí, para que estas ideas aparezan amparadas polo seu contexto xenuíno, que a escritura era unha innovación relativamente recente en Grecia. Cando Platón redacta os seus diálogos non había máis de dous séculos que os helenos a coñecían, e de ningún xeito se pode dicir que fose xa unha práctica habitual entre os intelectuais, pois aínda estaba relegada fundamentalmente a certas aplicacións burocráticas e comerciais. De todas as formas, non é ilexítimo considerar, nos termos de Umberto Eco, que Platón e, sobre todo, o seu mestre Sócrates foron os primeiros apocalípticos diante da revolución tecnolóxica, comunicativa e humanística que deu lugar á Galaxia do alfabeto.

Porque cando Marshall McLuhan cuña ese termo que tanto éxito acadaría, consistente en identificar como Galaxia Gutenberg o ciclo da modernidade inaugurado pola invención da imprenta de tipos móbiles, deixa así mesmo implicitamente instaurada a definición das dúas Galaxias precedentes, a da oralidade e a do alfabeto. E posibilita tamén que o seu propio nome sexa utilizado 
para identificar a nosa época contemporánea no que se refire ás tecnoloxías «eléctricas» da comunicación, inaugurada a mediados do XIX coa invención pioneira do telégrafo, ao que virían a secundar despois o teléfono de Graham Bell, o cinematógrafo dos Lumière, a radio de De Forest e Marconi, e finalmente a televisión, que xa está lista no decenio dos trinta pero que deberá agardar ao final da Segunda Guerra Mundial para o seu universal espallamento ata o punto de converterse, segundo McLuhan, no «medio eléctrico más significativo porque impregna casi todo hogar en el país, extendiendo el sistema nervioso central de cada espectador, a medida que trabaja y moldea el sensorium completo con el último mensaje» (McLuhan, Zingrone, 1998, p. 294).

Esta nova Galaxia que segue á de Gutenberg, a cuarta se temos en conta previamente as da oralidade e do alfabeto, é, xa que logo, recoñecida polos filósofos da chamada Transmodernidade, entre eles Rosa María Rodríguez Magda (2003 e 2004), como a «Galaxia McLuhan». Nela, loxicamente, a irrupción da nova tecnoloxía representa a posibilidade certa dunha muda da condición humana como o propio MacLuhan advertía xa en 1962: "la imprenta comporta el poder individualizador del alfabeto fonético mucho más allá que la cultura del manuscrito pudo hacerlo jamás. La imprenta es la tecnología del individualismo. Si los hombres decidieran modificar esta tecnología visual con la tecnología eléctrica, el individualismo quedaría también modificado. Promover una lamentación moral acerca de ello es como soltar tacos contra una sierra mecánica porque nos ha cortado los dedos» (1969, p. 224).

$\mathrm{O}$ investigador canadense morreu en 1980, e no cuarto de século que nos separa do seu pasamento ocorreron acontecementos transcendentais para a historia da humanidade vista desde a perspectiva que McLuhan fixera súa. Nos seus escritos xa se menciona o ordenador como un instrumento máis de fixación electrónica da información, pero o máis interesante para nós resulta, sen dúbida, a pegada profética que nalgúns momentos McLuhan manifesta a este respecto. Así, cando no seu libro de 1962 trata de como a nova interdependencia electrónica recrea o mundo a imaxe e semellanza dunha aldea global, escribe: «En lugar de evolucionar hacia una enorme biblioteca de Alejandría, el mundo se ha convertido en un ordenador, un cerebro electrónico, exactamente como en un relato de ciencia ficción para niños. $\mathrm{Y}$ a medida que nuestros sentidos han salido de nosotros, el GrAN HERMANO ha entrado en nuestro interior» (1969, p. 55). 
Uns poucos anos máis tarde, na extensa entrevista que unha coñecida e moi popular revista norteamericana lle fixera, McLuhan expresa unha premonición referida aos ordenadores que fala do que naquel momento non era máis ca un soño e, polo contrario, hoxe é a realidade máis determinante do que, con Manuel Castells (2001), imos denominar a Galaxia Internet. Dicía McLuhan: "el ordenador mantiene la promesa de engendrar tecnológicamente un estado de entendimiento y unidad universales, un estado de absorción en el logos que pueda unir a la humanidad en una familia y crear una perpetuidad de armonía colectiva y paz. Éste es el uso real del ordenador, no como acelerador del marketing o de la resolución de problemas técnicos, sino como acelerador del proceso de descubrimiento y orquestación de ambientes y energías terrestres $-\mathrm{y}$ eventualmente galácticos. La integración comunal psíquica, lograda al fin por los medios electrónicos, podría crear la universalidad de conciencia prevista por Dante cuando predijo que los hombres continuarían siendo poco más que fragmentos rotos hasta que se unificaran en una conciencia inclusiva. En un sentido cristiano es meramente una nueva interpretación del cuerpo místico de Cristo; y Cristo, después de todo, es la última extensión del hombre» (McLuhan, Zingrone, 1998, p. 314).

Nas últimas palabras transcritas asoma unha das peculiaridades do autor, a súa condición confesa e militante de católico que tanto lles sorprende a algúns dos seus lectores, como tamén a expresión aforística do seu pensar e o desenvolvemento fragmentario, a cachón, das súas ideas. Todo isto únese a unha certa pose de adiviño que McLuhan cultiva, pois pensa que mesmo os analistas máis certeiros da realidade cultural e social van sempre un paso por detrás dela no tocante á súa visión do mundo, de xeito que perciben como un todo orgánico e comprensible soamente o contexto que precedera ao que na actualidade están a vivir. Isto é o que el denominaba "visión de espejo retrovisor» (McLuhan, Zingrone, 1998, p. 284), contra a que combateu, precisamente, cos seus pulos proféticos.

Ás veces, por exemplo, cando acreditaba a data exacta da desaparición do libro, errou clamorosamente, pero cómpre recoñecerlle perspicacia máxima no vaticinio de cal chegaría a ser a verdadeira revolución da Galaxia Internet. Sobre todo, se temos en conta a cronoloxía, pois estamos a falar dun proceso moi curto no tempo para o que foi a transcendencia das profundas modificacións xa intro- 
ducidas non só en termos de tecnoloxía senón tamén no que atinxe á propia condición humana.

O primeiro ordenador capaz de ser programado, o famoso ENIAC (Electronic Numerical Integrator and Calculador), é froito inmediato da Segunda Guerra Mundial. O UNIVAC, a primeira computadora de uso comercial é de 1951, e a serie 360 de IBM, pioneira entre os ordenadores de empresa, é un pouco posterior á aparición do libro $A$ Galaxia Gutenberg. Nos anos setenta, desenvólvense os microprocesadores. Informáticos mozos como Jobs ou Wozniak constrúen o Appel II, mentres que Bill Gates e Paul Allen evolucionan a linguaxe de programación BASIC. Pero é despois da morte de McLuhan, xa no ano 1981, cando se venden un millón de microordenadores VIC-20 de Commodore, o que impulsa a IBM a entrar neste mercado. En 1983, chega á feira SIMO de Madrid o primeiro PC de IBM en España, cun prezo de 400000 pesetas, que vén acompañado do DYNA TAC, o primeiro terminal móbil de Motorola, coñecido popularmente como «o ladrillo». A finais do decenio dos oitenta, o CD-Rom posibilita a eclosión dos portátiles.

Aquela pegada vaticinadora de Marshall McLuhan cobra todo o seu mérito se reparamos nesta outra secuencia cronolóxica. De 1972 data a primeira demostración de ARPANET, unha rede de ordenadores creada en 1969 desde a Universidade de California en Los Ángeles pola Advanced Research Projets Agency (ARPA) do Departamento de Defensa dos Estados Unidos. En 1983, créase a rede MILNET, exclusivamente para fins militares, e aparece ARPA-INTERNET, dedicada á investigación baixo control da NSF, a National Science Foundation. A súa privatización xa nos anos noventa coincide coa achega, xusto en 1990, do sistema de hipertexto coñecido como World Wide Web por parte do programador inglés Tims Berners-Lee, empregado no CERN -o centro europeo de investigación en física das altas enerxías. Logo virán a comercialización, en decembro de 1994, do Netscape Navigator e a difusión que desde un ano máis tarde Microsoft fai do Internet Explorer como parte do seu Windows 95, de xeito que a suma de semellantes achegas permitiu finalmente o nacemento da Galaxia Internet. Manuel Castells (2001, p. 31) ratifícao con toda rotundidade: «A pesar de que Internet estaba ya en la mente de los informáticos desde principios de los sesenta, que en 1969 se había establecido una red de comunicación entre ordenadores y que, desde finales de los años sesenta, se habían formado 
varias comunidades interactivas de científicos y hackers, para la gente, para las empresas y para la sociedad en general, Internet nació en 1995».

Quere isto dicir que, cando cumprimos a primeira ducia de anos mergullados na nova Galaxia, aínda non podemos dar por superado o que ben poderiamos chamar o "período incunable» da nova cultura xerada pola Internet. Mais abonda o tempo pasado para preguntármonos se se poden detectar xa ou non os seus efectos, máis ou menos evidentes, na propia condición humana. Aqueles moi noviños espectadores da representación madrileña de Historia de una escalera terían, cando o comezo da Internet, os mesmos anos ca min cando a televisión comezou a súa andaina en España. Á miña casa aínda tardaría un lustro en chegar a pequena pantalla, pero eles sen dúbida accederon máis axiña á rede, ben na escola, ben no seu domicilio: os tempos van agora moito máis prestos. De todos os xeitos, supoño que comparto con eles un mesmo acomodo na Galaxia Internet, aínda que para min non é este o balbordo en que nacín, crecín e aprendín a ler. Probablemente, no caso de que a súa lectura cómica do drama de Buero Vallejo, tan allea á miña propia sensibilidade, fose froito dun ha mediación externa, moi poderosa, eu pensaría antes na influencia da Galaxia McLuhan, e dentro dela da omnipresente televisión, que da responsabilidade da Internet.

Igual que acontecera coa arribada da escritura -lembremos a actitude de Sócrates- ou co invento da imprenta -á que o propio McLuhan, certamente moi de paso, chega a atribuír o espallamento da esquizofrenia e a alienación como «consecuencias inevitables» da alfabetización fonética (McLuhan, Zingrone, 1998, p. 291)-, é lexítimo facérmonos a mesma pregunta que fai o apocalíptico Sven Birkerts: "¿por qué tan poca gente se pregunta hasta qué punto no estaremos cambiando nosotros mismos ni si estos cambios son para bien?» (Birkets, 1999, p. 285). As respostas que el mesmo atopa son todas elas negativas e ameazantes. Os medios tecnolóxicos afástannos cada vez máis do natural, alléannos do noso ser fundamental. Unha poderosa cortina electrónica interponse entre cada un de nós, os demais, a natureza e, en definitiva, a realidade. Se cada individuo posúe unha "aura» propia -o termo vén tomado de Walter Benjamín e a súa definición da obra de arte-, unha presenza única, estamos a sufrir unha erosión gradual pero constante da devandita presenza humana, tanto no plano individual como no do conxunto da nosa especie. O resultado final será, inexo- 
rablemente, a superficialidade total -Marcuse falaba tamén de «unidimensionalidade». Fuxindo da profundidade inherente ao ser humano ata hoxe, estamos a afacernos «a la seguridad prometida de una vasta conectividad lateral» (Birkerts, 1999, p. 293).

Non é doado, quizais por falta de abonda perspectiva temporal, identificar os síntomas máis salientables da resposta humana ás condicións subxectivas e obxectivas que as novas tecnoloxías impoñen. Temos, porén, algunhas aproximacións, popperianamente válidas en canto falsables, que contrapoñen conceptos identificados, por caso, coa tríade teselantítese/sintese que a filósofa Rosa María Rodríguez Magda (2003) vencella, respectivamente, coa modernidade, a posmodernidade e o que ela denomina transmodernidade. Modernidade é tanto como Galaxia Gutenberg, a posmodernidade corresponde á Galaxia McLuhan e, finalmente, a transmodernidade xurdiría do que ela denomina Galaxia Microsoft e nós preferiremos chamar Galaxia Internet.

Xogando cun cadro de atributos, contrapostos en tríades, de cada unha destas Galaxias, na primeira das columnas destacan trazos ben definidos, que propician a cohesión, a afirmación, o pensamento forte, racionalista. A segunda columna, a posmoderna, é antitética: disgregación, multiplicidade, negación, pensamento feble. E, por último, a terceira mantén o xesto definidor da primeira, pero orfo de todo fundamento nunha sorte de «clausura especular».

Bástenos con mencionar algunhas das posibles tríades consonte o xogo proposto, comezando pola oposición entre realidade moderna, simulacro posmoderno e virtualidade transmoderna. Todo isto equivale correlativamente a presenzalausencialtelepresenza. Corresponde, respectivamente, a centramentol dispersión/rede.

A razón contraponse á reconstrución e ao pensamento único. Ao coñecemento, o antifundamentalismo escéptico e a información. Se a modernidade posuía un pulo global, a posmodernidade opta polo local e a transmodernidade ábrelle a porta a unha síntese: o glocal, termo cuñado por R. Robertson. Ao imperialismo sucédelle o poscolonialismo e logo vén o cosmopolitismo transétnico; á xerarquía séguelle a anarquía e o caos integrado. Outra tríade significativa é a que contrapón átomo, cuanto e bit.

Se unha economía industrial foi substituída pola economía postindustrial, agora prima unha nova economía. O público deulle paso ao privado posmoderno 
e hoxe vivimos xa mergullados na obscenidade da intimidade. A alta cultura da modernidade foi suplida pola cultura de masas da que tratara Umberto Eco, e esta pola cultura de masas personalizada na transmodernidade. E xa no propio núcleo das tres Galaxias sucesivas, Gutenberg, McLuhan e Internet, a escritura, a obra, o narrativo, a prensa da primeira contrastan co texto, o visual, a televisión e en xeral os mass-media da segunda, e o hipertexto, os multimedia, o ordenador e a rede da transmodernidade.

Entre o apocaliptismo puro e a integración entusiasta hai matices intermedios, por suposto. Lembro, por caso, a posición de James O'Donnell (2000), un cincuentón norteamericano de orixe irlandesa, profesor de estudos clásicos e especialista en Agustín de Hipona, que desempeña as funcións de vicerreitor de sistemas de información e informática na Universidade de Pennsylvania. No seu libro sobre os avatares da palabra desde o papiro ao ciberespazo móstrasenos coma un integrado que escribe, así e todo, desde unha intensa conciencia apocalíptica. O'Donnell dubida sobre o futuro do libro, dos autores, da lectura, das bibliotecas, das Humanidades académicas e das propias universidades. Recea tamén que os novos tempos acaben por marxinar a libreiros, escritores, lectores, bibliófilos, humanistas e profesores. A esta Espada de Damocles tenta responderlle cun talante elegante e positivo, non exento de voluntarismo, porque, como el mesmo di, «estudio el pasado, pero proyecto vivir en el futuro» (2002, p. 23). Precisamente por iso, toma a Casiodoro, autor sobre o que versou a súa tese de doutoramento, como símb olo do que debería ser a actitude dos mestres humanistas no novo teatro universal do ciberespazo. Así como o autor das Institutiones, desde o seu retiro monástico da costa italiana, dedicoulle todas as súas enerxías a preservar dos bárbaros a civilización clásica decadente, habilitando os monxes como copistas eficaces da erudición grecolatina, O'Donnell entende que non moi diferente resulta a súa traxectoria persoal de filólogo que dera o salto desde as súas habelencias mecanográficas xuvenís ata o manexo de procesadores de textos rudimentarios como o Kaypro II, ata a visita asidua, vía módem, de bases de datos en liña ou a edición electrónica dunha revista de estudos clásicos. E engade a seguinte confidencia: «en algún momento del proceso comencé a darme cuenta de una ironía. Yo había llegado a ser como Casiodoro. No porque fuese cristiano o erudito, sino porque, más o menos conscientemente, ayudaba en la tarea de crear, para la gente y las ideas que yo 
valoraba, un espacio útil en el nuevo ambiente tecnológico» (O’Donnell, 2000, p. 185).

Resulta ocioso engadir que eu, persoalmente, síntome moi identificado, biográfica pero tamén ideoloxicamente, con esta postura. Que xa fora, por certo, proposta por Marshall McLuhan, quen en 1969 denunciaba que se os occidentais alfabetizados estivesen realmente interesados en preservar os aspectos máis creativos da súa civilización, deixarían de estar de mans cruzadas lamentando os cambios para mergullarse no vértice da nova tecnoloxía co obxecto de controlar a nova Galaxia.

Hai unha expresión súa que é digna de ser repetida hoxe e aquí: McLuhan pide que se cambie a «torre de marfil» por unha «torre de control» (McLuhan e Zingrone, 1998, p. 317). E neste importante texto seu, xa citado, que non pertence a un dos seus grandes libros senón a unha entrevista xornalística, vén a confluír no que a nós máis no interesa, no terreo da educación en xeral e da educación audiovisual en particular. Para isto, é necesaria a racionalización de novas estratexias docentes, porque -son as súas palabras- «esperar que un niño crecido en la era eléctrica responda a las formas de educación antigua, es como esperar que un águila nade. Esto simplemente no está dentro de su ambiente, por lo tanto es incomprensible» (McLuhan e Zingrone, 1998, 299).

$\mathrm{O}$ autor canadense falaba na citada entrevista dos «nenos televisivos» como actores da Galaxia Gutenberg, pero nós xa estamos na Galaxia Internet e por iso Nicholás Negroponte emprega, pola súa banda, a expresión "nenos dixitais» (1999, p. 272). Por certo, non sei se os meus coespectadores de Historia de una escalera responderían mellor a unha ou a outra desas denominacións: probablemente a ambas as dúas. Malia que un daqueles nenos de McLuhan, segundo algúns cálculos, ingresaba na gardería con 4000 horas de televisións ás súas costas, o pensador coidaba que con eles seguía a ser enteiramente posible unha «mestura creativa» das dúas culturas, a alfabético-gutenberiana e a «eléctrica».

Porque a secuencia de Galaxias, a sucesión deses cinco ciclos que irían da oralidade á Internet, non representa compartimentos estancos e tránsitos irreversibles. O propio McLuhan lembraba como os sistemas de comunicación eléctrica -pensemos na radio e na televisión- representaron un claro retorno da oralidade á esfera da comunicación humana e á transmisión cultural. Certamente, a pegada da voz e a función determinante do sentido da audición marcan de novo o sécu- 
lo XX, onde, se reparamos ben no asunto, a televisión doméstica se constrúe sobre os alicerces xenéricos e temáticos da radio, ata o punto de que algúns teóricos da comunicación falan a este respecto de audiovisión. Pois ben, unha regresión semellante está claro que se produce entre a Galaxia Internet e a Galaxia Gutenberg. Umberto Eco (Nunberg, 1998, p. 305) clausuraba en 1994 un simposio sobre o futuro do libro advertindo que «la característica principal de una pantalla de ordenador es que alberga y muestra más letras que imágenes. La nueva generación se acercará al alfabeto más que a las imágenes. Volvemos de nuevo a la Galaxia Gutenberg, y estoy seguro de que si McLuhan hubiera sobrevivido hasta la carrera de Apple hacia el Silicon Valley, se hubiera maravillado ante este acontecimiento portentoso». Non é de estrañar, xa que logo, que T. Nelson, un dos gurus do hipertexto, lles chame aos ordenadores «máquinas literarias».

Para que a Galaxia Internet propicie un reforzamento da lectoescritura como alicerce da educación humana é necesario que se leven a cabo estratexias docentes ben construídas e plenamente conscientes dos obxectivos que se perseguen, o que era un dos cabalos de batalla do último McLuhan, convencido un tanto hiperbolicamente, como ás veces lle gustaba manifestarse, de que as escolas dos anos sesenta/setenta eran «institucións penais intelectuais» (McLuhan e Zingrone, 1998, p. 300).

Comecei estas páxinas co relato dunha experiencia persoal desacougante: a abraiante e risoña representación de Historia de una escalera. Cómpre que agora, abusando unha vez máis da paciencia dos meus lectores, bote man doutra vivencia que foi, polo contrario, plenamente engaiolante para min.

Alá polo outono de 2002 fun convidado a visitar en Arteixo o Centro de Desenvolvemento e Tecnoloxía vinculado pola Fundación Amancio Ortega ao proxecto Ponte dos Brozos. O devandito proxecto pretendía a mellora dos procesos de ensino e aprendizaxe no contexto da Galaxia Internet a partir do traballo en tres centros do Concello de Arteixo que abranguían o segundo ciclo de infantil, primaria, ensino secundario obrigatorio, bacharelato e ciclos formativos de FP.

Nas aulas piloto que visitei, os lapiseiros, mapas, libros e a plastilina de cores convivían con ordenadores de sobremesa e portátiles, con pantallas dixitais, escáneres e impresoras. A conectividade estaba garantida e formaba parte do conxunto de recursos para o ensino e a aprendizaxe que os alumnos dispuñan con absoluta facilidade. 
Nunca esquecerei, tampouco, que na gran pantalla da aula, así como nas pequenas dos ordenadores, aparecía un texto, un fragmento da noveliña picaresca Lazarillo de Tormes. E que a fonte da que procedía eran os fondos dixitalizados da Biblioteca Virtual Miguel de Cervantes, que fora fundada na Universidade de Alacant pouco antes daquela visita, concretamente en 1999.

Desde aquela, a Biblioteca Virtual (http://www.cervantesvirtual.com) serviu trescentos cincuenta millóns de páxinas: o mes de novembro de 2006 foron once millóns e medio, das que menos do corenta por cento foron solicitadas desde Europa. O catálogo da biblioteca oferta 23000 rexistros bibliográficos, que están a ser incrementados día a día. A cifra, aínda que modesta se a comparamos cos fondos das mellores bibliotecas físicas, é meritoria no eido virtual se temos en conta que o Gutenberg Project, fundado nos primeiros anos setenta como un banco de textos informatizados, dispón de 19000 títulos e recibe mensualmente dous millóns de descargas.

A Biblioteca Virtual Miguel de Cervantes posúe unha tripla condición. É, por unha banda, unha colección de materiais dixitalizados, tanto a partir de documentos xa existentes, impresos ou audiovisuais, como producidos orixinariamente de forma dixital polos talleres da propia biblioteca. Pero, por outra, estamos tamén diante dun Centro de Investigación sobre a aplicación das ferramentas que lles proporcionan as novas tecnoloxías á investigación humanística, á edición dixital e ao desenvolvemento das bibliotecas virtuais. Finalmente, preténdese tamén contar cun vehículo axeitado para propiciar o espallamento das culturas hispánicas, entendendo por tales as fundadas sobre as linguas orixinais da Península Ibérica.

Xa que logo, a literatura desas linguas, producida no ámbito iberoamericano, a hemeroteca e a enciclopedia interpretativa das obras literarias e as súas referencias críticas conforman os tres alicerces da Biblioteca Virtual Miguel de Cervantes.

Entre os seus fondos conta con máis de vinte portais temáticos, como os dedicados ao exilio, a países americanos como Venezuela, á Literatura gauchesca, á infantil e xuvenil, á historia e crítica do cinema español, etc., portais institucionais como o Joan Lluis Vives, os das Bibliotecas Nacionais de Arxentina e Chile, o Colexio de México, etc., e trinta e nove bibliotecas de autores clásicos e contemporáneos entre os que se atopan desde Martín Codax, Cervantes ou 
Calderón ata Leopoldo Alas, Nicolás Guillén, Emilia Pardo Bazán ou Mario Benedetti.

Unha Biblioteca de Historia, outra de Signos, especialmente concibida para persoas con dificultades auditivas, unha Fonoteca con máis de mil arquivos e unha Videoteca con preto de mil vídeos de produción propia e materiais doutras procedencias son as seccións que completan esta outra faciana do seu catálogo, que inclúe máis de oito mil títulos.

En 2004, Google anunciou o seu proxecto de envorcar na rede, en aberto, quince millóns de libros procedentes de entidades públicas como bibliotecas, universidades ou outras institucións culturais. A iniciativa do líder mundial entre os buscadores da Internet atopou axiña serias dificultades, relacionadas sobre todo co complexo asunto dos dereitos de autor e de copia, pero xa é accesible un programa para buscar libros de Google (http://www.books.google.es) que permite acadar información básica sobre obras das que non hai vista previa dispoñible, acceder á vista dalgúns fragmentos do texto solicitado ou, mesmo, un número limitado das súas páxinas.

Diante da aparente modestia dos díxitos que a Biblioteca Virtual Miguel de Cervantes manexa, en comparación coas magnitudes millonarias que Google promete, hai que facer unha distinción determinante. Non é o mesmo elaborar un gran banco de textos bibliográficos posto na rede mediante a mera dixitalización facsimilar dos libros orixinais que construír unha auténtica biblioteca virtual, concibida para prestarlles aos seus usuarios deslocalizados os mesmos servizos que unha biblioteca tradicional. Non se trata, soamente, da información e a orientación necesarias para transitar con garantías de éxito pola frondosa selva da produción escrita que a humanidade acumula ao longo de máis de dous milenios. Hai que proporcionar tamén todo un amplo abano de ferramentas lingüísticas e hipertextuais que lle achegarán valor engadido á mera existencia dunha determinada obra na Internet. Unha biblioteca virtual pode ser en si mesma unha construción intelectual enriquecedora e non un simple almacén dixital de textos, o que esixe un lapso razoable de tempo e os investimentos axeitados.

Un dos problemas da Internet é unha certa confusión entre información e coñecemento, así como o perigo de provocar unha especie de infocaos. Bibliotecas virtuais como a Miguel de Cervantes están pensadas precisamente para evitalo, ofrecendo o canón das literaturas rigorosamente reproducido e arroupado 
coas achegas da investigación filolóxica e literaria. Pero xunto ao dito, o que se pretende é achegarlles a aqueles «nenos televisivos» ou «nenos dixitais», a través da pantalla, a lectura dos textos.

José A. Antonio Millán (2001, p. 21), un dos nosos máis acreditados expertos na Galaxia Internet, sostén a tese, que eu comparto sen reservas, de que a lectura é a chave do coñecemento na sociedade da información. A rede proporciona esta última a mancheas, en termos nunca antes logrados, pero non abonda con iso. O único instrumento para a absorción individual da información e a súa transformación en coñecemento é a lectura, que é unha actividade individual, creativa, pero susceptible de ser inducida e titorizada polo profesor.

George Steiner (2006, p. 96), unha das máximas figuras do humanismo contemporáneo, querería ser lembrado como un «bo mestre de lectura». E o prematuramente desaparecido comparatista e intelectual palestino, Edward Said, afirmaba pouco antes do seu pasamento que o seu traballo como humanista era precisamente a lectura de textos fundamentais, procedesen de onde procedesen.

Procedesen de onde procedesen: por exemplo, engado pola miña parte, dos fondos dunha biblioteca virtual. «Lo que yo enseño -concluía Said (2003, p. 82) e eu tamén remato coas súas palabras- es cómo leer». 


\section{BIBLIOGRAFÍA}

BIRKERTS, S.: Elegía a Gutenberg. El futuro de la lectura en la era electrónica, Madrid, Alianza Editorial, 1999. Bourdieu, P.: Sur la televisión, París, Liber-Raison d'agir, 1996.

Bustamante, E. (comp.): Hacia un nuevo sistema mundial de comunicación. Las industrias culturales en la era digital, Barcelona, Gedisa, 2003.

Castells, M.: La era de la información. La sociedad red, vol. I, Madrid, Alianza Editorial, 1997.

CASTElls, M.: La era de la información. Economia, sociedad y cultura, vol. II, Madrid, Alianza Editorial, 1998a.

CAStells, M.: La era de la información. Fin de milenio, vol. III, Madrid, Alianza Editorial, 1998b.

Castells, M.: La Galaxia Internet. Reflexiones sobre Internet, empresa y sociedad, Barcelona, Plaza \& Janés, 2001.

CaVAlli SforzA, L. L.: La evolución de la cultura, Barcelona, Anagrama, 2006.

ECO, U.: Apocalipticos e integrados ante la cultura de masas, Barcelona, Lumen, 1968.

FERnÁNDEZ, C. (comp.): Culturas, civilizacións e sociedade global, Vigo, Galaxia / Fundación Carlos Casares, 2005.

GÓMEZ de Liaño, I.: El idioma de la imaginación, Madrid, Taurus, 1982.

GonzÁlez Quirós, J. e K. GHERAB MARTín: El templo del saber. Hacia la biblioteca digital universal, Barcelona, Ediciones Deusto, 2006.

LLEDÓ, E.: El surco del tiempo. Meditaciones sobre el mito platónico de la escritura y la memoria, Barcelona, Crítica, 1992.

Mcluhan, E. e F. Zingrone (comp.): McLuhan. Escritos esenciales, Barcelona, Paidós, 1998.

McLuhan, M.: La Galaxia Gutenberg. Génesis del Homo Typographicus, Madrid, Aguilar, 1969.

McLuhan, M.: Understanding Media. The Extensions of Man, Cambridge/London, The MIT Press, 1994.

Millán, J. A.: La lectura y la sociedad del conocimiento, Madrid, Federación de Gremios de Editores de España, 2001.

Murray, J.: Hamlet en la holocubierta. El futuro de la narrativa en el ciberespacio, Barcelona, Paidós, 1999. Negroponte, N.: El mundo digital. Un futuro que ya ha llegado, Barcelona, Ediciones B. S. A., 1999.

NunberG, G. (comp.): El futuro del libro. ¿Esto matará eso?, Barcelona, Paidós, 1998.

O’Donnell, J.: Avatares de la palabra. Del papiro al ciberespacio, Barcelona, Paidós, 2000.

Platón: Diálogos, México, Porrúa, 1984.

Rodríguez Magda, R. M.: La sonrisa de Saturno. Hacia una teoría transmoderna, Barcelona, Anthropos, 1989.

Rodríguez Magda, R. M.: «La globalización como totalidad transmoderna», Claves de Razón Práctica, 134 (2003), p. 22-30.

Rodríguez Magda, R. M.: Transmodernidad, Barcelona, Anthropos, 2004.

SAID, E.: The Art of Reading/El arte de leer, Universidad de Oviedo, 2003.

SASSOON, D.: Cultura. El patrimonio común de los europeos, Barcelona, Crítica, 2006.

SENNETT, R.: La cultura del nuevo capitalismo, Barcelona, Anagrama, 2006.

STEINER, G.: La muerte de la tragedia, Barcelona, Azul Editorial, 2001 (primeira edición de 1961).

STEINER, G.: Lecciones de los maestros, Madrid, Siruela, 2004.

Terceiro, J. B.: Socied@d digit@l.Del homo sapiens al homo digitalis, Madrid, Alianza Editorial, 1996. Terceiro, J. B. e G. Matías: Digitalismo. El nuevo horizonte sociocultural, Madrid, Taurus, 2001. 